UDC 624.131

DOI https://doi.org/10.32782/2664-0406.2021.39.4

Bobrakov A.A.

ORCID: 0000-0002-7915-2642

Ph.D., Associate Professor, Associate Professor at the Civil Engineering

and Project Management Department,

"Zaporizhzhia Polytechnic" National University, Zaporizhzhia

\title{
Shcherbyna L.V.
}

ORCID: 0000-0002-1870-5127

Ph.D., Associate Professor, Associate Professor at the Civil Engineering

and Project Management Department,

"Zaporizhzhia Polytechnic” National University, Zaporizhzhia

\section{Donenko I.V.}

ORCID: 0000-0002-0017-9018

Ph.D., Associate Professor at the Civil Engineering and Project Management Department,

"Zaporizhzhia Polytechnic" National University, Zaporizhzhia

\section{Ishchenko O.L.}

ORCID: 0000-0002-4152-6135

Assistant Professor at the Civil Engineering and Project Management Department, "Zaporizhzhia Polytechnic" National University, Zaporizhzhia

\section{INFLUENCE OF HUMAN FACTOR TO THE HYDROLOGICAL CONDITIONS OF AREA AT THE EXAMPLE OF ZAPORIZHZHIA REGION}

\begin{abstract}
Ensuring the necessary operational reliability of buildings and structures when flooding the urban area with groundwater and man-made waters requires further development of methods of assessment of the architectural and construction system, which interacts with environmentally harmful natural and man-made environment. The purpose of the article is the analysis of urban, geotechnical and geo-ecological features of the engineering infrastructure of the territory; classification of negative flooding factors that impair the conditions of operation of urban development objects; classification and selection of measures aimed at improving the operational reliability of the foundations and foundations, buildings and structures of the city under the influence of negative factors of flooding. As a result of the widespread rise of groundwater, moved to the upper thickness of the loessy loam and this significantly increased their mineralization, because of this groundwater ceased to be used as potable and as a result of their aggressiveness towards building materials, began to contribute to the corrosion process. Problems of protecting urban buildings from negative consequences of flooding by groundwater and man-made water affect many aspects of engineering activity and represent and this is typical for modern urbanized territories. For the successful implementation of large-scale measures to protect the city's engineering infrastructure from flooding and to develop engineering measures aimed at ensuring the operational reliability of buildings and structures, it is necessary to develop a fully functional municipal urban information system.
\end{abstract}

Key words: hydrogeological conditions, groundwater, culverts facilities, building, city information system.

Problem statement. The common problem of exploitation ofurbanareasistheimplementation of environmental - rehabilitation measures aimed at improving the urban environment through the suspension of the impact of adverse natural and man-made factors. One of such 
negative and long-lasting factors is the flooding of urban areas with groundwater of natural and man-made character for most modern urban areas. During the last 50 years, the flooding of the territory and related problems became a great problem for Ukraine.

Ensuring the necessary operational reliability of buildings and structures when flooding the urban area with groundwater and manmade waters requires further development of methods of assessment of the architectural and construction system, which interacts with environmentally harmful natural and man-made environment.

Analysis of recent research and publications. Currently in Ukraine researchers such as I. Sanina, N. Lyuta, A. Lushchyk, V. Shestopalov, V. Lialko, V. Hudzenko and others are engaged in the problems of exploitation of urbanized territories, in the search for rehabilitation measures to stop the effects of adverse natural and technogenic factors. These solutions are reflected in the scientific and technical $[4 ; 5 ; 6]$ and regulatory literature $[1 ; 2 ; 3]$. However, the issues of flooding urban areas with groundwater are not adequately addressed.

The purpose of the article. The purpose of the article is to analyze the urban, geotechnical and geo-ecological features of the engineering infrastructure of the territory; classification of negative flooding factors that impair the conditions of operation of urban development objects; classification and selection of measures aimed at improving the operational reliability of the foundations and foundations, buildings and structures of the city under the influence of negative factors of flooding.

Presenting main material. In general, the area of natural and man-made flooding is about 7 million hectares or about $12 \%$ of the country territory. During the period of extreme precipitations or floods, they increase more than twice so the territory about 16 million hectares it is about $27 \%$ of Ukraine territory.

No one region of Ukraine can suffer because of flooding and other negative processes.

In Ukraine more than 2000 villages, 540 cities, 100 thousand hectares of agricultural area can suffer.

For Zaporizhzhia region flooding is a great problem. We can see in on statistic by this region. About 119 settlements are constantly flooded in this region, but during the periods of extreme precipitation and floods its number increases, for example 248 settlements suffered because of it.

Zaporizhzhia region is located in the southeastern part of Ukraine. The area of the region is 27.5 thousand $\mathrm{km}$. Mostly is a steppe plain, this area has many rivers, gullies with a slight slope to the north-west. To the south, the marks are getting lower to zero close to Azov Sea.

The area is located in central and southern steppe zones of Ukraine, almost all its surface grown the remains of virgin steppe vegetation survived just along the slops of the ravines and gullies. There are a few forests and shrubs.

The highest elevation is the central part of a region, which coincides the Pryazov crystalline massif (absolute mark 200-220 m).

The region consists of four hydrogeological districts:

- South-eastern line Dnepr massif;

- North-eastern part of Black Sea watershed (Small Artesian watershed);

- Western part of the Azov crystalline massif;

- North-eastern part of Black Sea cavity (artesian basin). Frozen lands are common in all four hydrogeological areas with predominance in the latter two.

The geological structure of Pryazov massif mostly consists of Quaternary and Precambrian rocks (south-eastern part) by the way a lot of crystalline rocks are going up to the surface (river valleys, gullies). That is why there are 2 dominated aquifers in this area:

- Aquifer horizon of cracked zones of crystalline rocks, which is the source of centralized water supply;

- Quaternary aquifer, which has separation distribution.

The quaternary aquifer timed in the watersheds to the Eolian-deluvia and diluvia loam, the sand. The capacity of the aquifer is $0.5-5 \mathrm{~m}$, less than $15-20 \mathrm{~m}$.

The flow of ground water to the surface observed in the upper and lower slopes to the beams.

In the region of the Black Sea lowlands (the southern part and the western half of the region), sedimentary deposits of the Credaceous, Paleogene, Neogene and Quaternary age (sands, clay, limestone, sandstones, loams) on the Precambrian rocks developed with a variable capacity of $100-1000 \mathrm{~m}$.

Such aquifers developed in the area: Cretaceous, Buchach, Torton, Cimmerian, Sarmatian, Pontic and Kulyalnskyi. Above 
of them the aquifer of the Qaternary deposits. Water-bearing rocks of groundwater are eoliandeluvial, deluvial. The capacity of the aquifer is usually $10-15 \mathrm{~m}$.

In the area of the Dnieper crystalline massif (northern part of the region) along with the wide development of crystalline rocks, Paleogene (sub-area), Neogene and Qaternary deposits are involved. The capacity of sediment deposits from several meters to $100-110 \mathrm{~m}$.

The aquifer horizons of cracked zones of crystalline rocks, Sarmatian and Pontic deposits are developed.

Cretaceous Paleogene, Neogeneand Qaternary sediments represent the Konska-Yalinska basin (mostly Guliyaipolsky, Pologivsky, partly Orichivsky and Kyibishevsky districts) with capacity of $40-400 \mathrm{~m}$. The main aquifers are the Buchach, Poltava and Sarmatian deposits. Qaternary aquifer timed, to the loaves of the Eolian-deluvial, delluvial and alluvial genesis. The groundwater Quaternary deposits of all four hydrogeological regions have free surface. Water-bearing loamy differences have a weak water-absorption; the debits of sources are predominantly hundreds and tenths of $1 / \mathrm{sec}$ $(0.3-0.05 \mathrm{l} / \mathrm{s})$. The nutrition of the quaternary aquifer is mainly due to atmosphere falling, the aquifer regime depends on season fluctuations. Chemically the water mostly mineralized. People use ground water for household purposes, less for drinking by capturing their mine pits.

Almost the whole territory except the northern part refers to the arid zones. Winter is short, not snowy, spring is shot and semi-dry, summer is long, very warm dry, and autumn is average duration and semi-dry. In dry years, the evaporation rate is twice higher then fate of falling. Rainfall characterized by not stability marks, which leads to drying of the soil and drought.

Analysis of climatic indicators shows that the existing of flooding directly depends on the precipitation and air temperature. Therefore, the biggest flooding was in 1985, 1997, and 2004, when annual average rainfall was twice higher the norm and the average of annual temperature was the lowest. There are three types of flooded lands:

1. Flat-knotted river floodplain.

2. Sloping slops of watersheds and beams with small saucers, salt marshes and waterlogged areas on weakly moderately salted bleak earth, soils-weakly middle saline, weakly drained
3. Flat leman-sea plane with steppe area on infertile saline and saline soil.

The territory of rivers is about $10 \mathrm{~km}$ and consists of nearly 60 rivers. Nearly half of them situated in the Territory of Dnipro River, and the other part at the territory of Azov.

The transverse line of the basins runs along the Azov crystalline massif with marks on the surface of $200-300 \mathrm{~m}$. The rivers of the Dnieper basin lie along the plain, the have a calm flow.

The slopes of the valleys are mostly flat, symmetrical, composed of a forest complex, which causes in some places a surface soil wash often at a considerable depth. The floodplain of rivers is usually two-sided, wide and at the time of spring can be flooded. The rivers of the Azov basin in some part have steeper and asymmetric high slops and separated small ravines. The processes of simultaneous erosion and accumulation are observed everywhere in the valleys of the Azov and Dnipro basin.

The analysis of the natural conditions of the region for a long period shows that raising the level of groundwater both in the country as a whole and in Zaporizhzhia began since the late 50s. The main reasons of large-scale groundwater rise are:

1. Overbuilding by the whole territory of Dnipro river.

2. Large scale plowing of land and water retention in agriculture.

Some reasons associated with the main reasons:

- wrong exploitation of the built reservoirs and pounds;

- building of irrigation canals without filter measures;

- lack of sewage in the countryside and at the territory cities and villages where private constrictions is located;

- violation of planning and building norms for settlements;

- bad conditions of drainage cuvettes for roads and railways.

As we can see, the main reason of flooding is human activity. By the end of the $90^{\text {th }}$ of the last century, the rise in groundwater level on agricultural lands was stabilized it depends of falling during the year. In settlements, the processes of deterioration of hydro-geological conditions continue to evolve exclusively due to the luck of landscaping.

Falling which were in autumn-spring periods 1997-1998 and 2004-2005 years led to 
flooding of the territory and caused damages to the national economy of Zaporizhzhia region.

Luck savage in settlements, in the presents of centralized water supply is one of the reason of a lot of flooding. In the most settlements, where drainage built, usually it not exploited and has bad technical conditions.

Now in the region we have 753 ponds and reservoirs, with a total capacity of about 162 million $\mathrm{m}^{3}$. Most of pounds are very small and they were made without projects and do not have drainage facilities. As a result, the girderriver territory reduced its drainage impact, because of it the groundwater level rises.

There are a several aquifers developed in this area: Cretaceous, Buchach, Torton, Cimmerian, Sarmatian, Pontic and Kylualnytsky. The aquifer horizon of the Quaternary deposits is above. Water-bearing rocks of groundwater are Eoliandeluvial, deluvial, in the floodplain of rivers and gullies - alluvial and alluvial-deluvial, on the sea terraces - leman-sea loam, sandy loam, less sand. The capacity of the aquifer is usually 10 ч $15 \mathrm{~m}$.

In the area of the Dnieper crystalline massif (northern part of the region) along with the wide development of crystalline rocks, Paleogene (sub-area), Neogene and Quaternary deposits are involved. The capacity of sediment deposits from several meters to 100 ч $110 \mathrm{~m}$.

The aquifer horizons of cracked zones of crystalline rocks, Sarmatian and Pontic deposits are developed. In quaternary sediments, groundwater confineding mainly to the Eoliandeluvial, deluvial and alluvial loamy loam, sandy loam, and lesser sands.

Under the influence of the above factors, the flooding of the land and settlements is practically observed in Melitopol (such as Molochna, Yushenly, Kuroshani), Tokmatskyi (such as Tokmachka, Molochnaya, Utliukskyi, Chingul, Kurochani) and Orichivskyy (Konka, Zerebets, Tersa) districts.

The backwater of existing ponds, siltation of small rivers in the lower reaches of the Sea of Azov and its estuaries, the most common in Berduansk, Yakimivka, Pryazovskyi areas. These are places for building of deaf dams on the rivers, gullies and drainage channels.

Dams and hydrotechnical structures, ponds, reservoirs are need for repair. All reservoirs and structures are operated in violation of the norms of current and major repairs. To date, the period of major repairs of most hydraulic structures exceeded the permissible several times, which threatens their destruction and flooding of the territories of settlements and arable lands located in the lower reservoirs. It is established that the areas with close groundwater level ( $2 \mathrm{~m}$ and below) are 85.3 thousand hectares, including: 15333h hectares - settlements (248 pieces), 70000 hectares - agricultural lands, including irrigated lands 1306 hectares.

In all mentioned areas, groundwater refers to the first from the surface of the aquifer, which has atmospheric power, as well infiltration power from underground communications and hydraulic structures (canals, collectors, etc.)

Based on the requirements of existing documents [1] flooded are considered:

- agricultural land with a constant groundwater level at a depth less than $1.5 \mathrm{~m}$;

- localities with occurrence of groundwater level at a depth of less than $2,0 \mathrm{~m}$.

The aquifer of the surface does not have a constant level. Its level depends on the intensity of falling, temperature regime during the year seasons, so level of the first aquifer changes since $1-1,5$ to $3-4 \mathrm{~m}$.

There are three categories on the total number of flooded settlements.

The first category includes settlements that require urgent centralized investments in the next 3-4 years. In these settlements, with the coincidence of advertise climatic conditions, there may be catastrophic consequences. There are nearly 15 such settlements in the district.

The second category includes settlements requiring planed centralized investments to prevent the rise of groundwater level. There are 28 of such settlements.

The third category are settlements what flooding not regular, and prevention measures solving locally. There are 205 settlements in the region.

Zaporizhzhia is the region center, located on the left and right sides of Dnipro River. From the northern side is Dnipro reservoir, from the south side Khakovska reservoir.

The hydrography of Zaporizhzhia territory represented by the river Dnipro, small rivers Mokra Moskovka, Sukha Moskovka, many streams and beams. The length of small rivers within the city is $26.0 \mathrm{~km}$, beams, streams $11.5 \mathrm{~km}$, beams $-22.3 \mathrm{~km}$.

The length of the river Dnipro within the city is $24.2 \mathrm{~km}$. The general falling of the river is about $11 \mathrm{~cm}$ per $1 \mathrm{~km}$. 
In Zaporizhzhia, the channel regulated by Dnipro and Kakhovka reservoirs, that is why changing of water level depends of the filling and emptying of reservoirs. Marking the water level in the upper by the Dnipro reservoir $47.9 \mathrm{~m}$. Mokra Moskovka River is the left tributary of Dnipro River. Watershed area $457 \mathrm{~km}^{2}$, the length of the river is $62 \mathrm{~km}$, within the city $-11 \mathrm{~km}$.

Zaporizhzhia is an industrial city with a developed industry. Residential development is a streamlined multistores buildings equipped with all utilities: water, gas, utility and storm sewer. There are also one-store building, which are manly located along the banks of the rivers. They were built long time ago without engineering projects. Many of these structures flooded by groundwater. Generally, 1011.5 hectares with 1608 buildings, including 74 many-stores buildings are flooded.

The main reasons for flooding are:

- floodplains of rivers, no security zones, as a result the channels are blackened, littered, overgrown with a reed and do not allow storm and flood and water;

- built car roads blocked the way of outflow of surface and groundwater in the Dnipro River and other watercourses and downgrades;

- the entrance of private houses, as a rule, are executed from a mound without converting structures, which led to the formation of closed platforms without outflow;

- the culverts under the highways are lack sometimes;

- in areas of partial construction there are no storm, economic and fecal wastewater, so all surface water and discharges of economic and fecal wastewater fall into the cesspools and go to replenish groundwater;

- leaks of water from old, long-established water areas.

The rise of groundwater level led to:

- the sanitary situation in the city gets worse, threat of epidemic among the people (malaria, cholera), because drains can appear at the surface;

- destruction of buildings, communications in resident sectors of the city will make worse the social conditions for living;

- the neglected warehouses of poisonous chemicals and cattle-breeders that fall into the flood zone are of particular danger.

As a result of the widespread rise of groundwater, moved to the upper thickness of the loessy loam and this significantly increased their mineralization, because of this groundwater ceased to be used as potable and as a result of their aggressiveness towards building materials, began to contribute to the corrosion process.

Problems of protecting urban buildings from negative consequences of flooding by groundwater and man-made water affect many aspects of engineering activity and represent and this is typical for modern urbanized territories.

The process of flooding and its influence to the building constructions of the city we can represent like this:

1. Primary factors of flooding (PFF) is the process of flooding, which occurs as the level of groundwater and their rising to the surface.

2. Secondary factors of flooding (SFF) - these are the consequences of the influence of primary factors to the soil massif and underground part of buildings. Secondary factors are changes in physical and mechanical properties of soils, changes in physical and mechanical building characteristics, wrong exploitation of buildings and its parts.

3. The third factor of flooding (TFF) is the effect of PFF and SFF in the form of deformation and other mistakes in exploitation of buildings and constructions, which in some cases may be dilapidated.

Depending of the type of buildings and structures these factors can lead in different way. Aggressive groundwater and subsidence of soil bases are significant to flooding factors.

Conclusions. For successfully protection of the engineering infrastructure from the flooding and to developing engineer measures for protecting buildings and structures, its necessary to develop municipal information system (MIS).

MIS includes: information field, built on topo-geodesic basis and includes the main infrastructure objects: buildings, structures, city system, etc. All major databases should integrate into a single cartographic material.

It's possible, step by step, creation of MIS through the integration the efforts of municipal services, project making organizations and its specialists, universities, etc. Successful creation of a managed system in Zaporizhzhia requires additional research and development to create a database and the MIS project itself. 


\title{
Bibliography
}

1. Захист від небезпечних геологічних процесів. Інженерний захист територій та споруд від підтоплення та затоплення. ДБН В.1.1-24:2009 від 1 січня 2011. Київ : Мінрегіон України. 2009.

2. Планування і забудова територій. (2018). ДБН В.2.2-12:2018. Київ : Мінрегіон України. 2018

3. Регіональна доповідь про стан навколишнього природного середовища у Запорізькій області у 2016 році. URL: https://www.zoda.gov.ua/files/WP_Article_File/original/000085/85864.pdf.

4. Гидрогеологические основы охраны подземных вод от загрязнения. Центр международных проектов Государственного комитета по науке и технологиям. Москва, 1984. С. 171-177.

5. Шестопалов В., Лялко В., Гудзенко В., Дробноход М., Огняник М., Руденко Ю., Ситников А., Скальський О., Сухоребрий А., Яковлєв Є. Підземні води як стратегічний ресурс (наукові засади дослідження підземних вод). Вісник Наиіональної академії наук України. 2005. Випуск 5. С. 32 - 38.

6. Саніна І.В., Люта Н.Г., Лущик А.В. Критерії оцінки екологічного стану геологічного середовища при проведенні регіональних еколого-геологічних досліджень. Київ, 2009. С. 28-41, 42-44.

\section{References}

1. Zakhyst vid nebezpechnykh heolohichnykh protsesiv. Inzhenernyi zakhyst terytoriy ta sporud vid pidtoplennya ta zatoplennya [Protection against hazardous geological processes. Engineering protection of areas and structures against flooding and unsettle]. (2009). DBN B.1.1-24:2009 from 1 ${ }^{\text {st }}$ January 2011. Kyiv: Minregion of Ukraine [in Ukrainian].

2. Planuvannya i zabudova terytoriy [Territory planning and development]. (2018). DBN B.2.2-12:2018. Kyiv: Minregion of Ukraine [in Ukrainian].

3. Rehionalna dopovid pro stan navkolyshnoho pryrodnoho seredovyshcha $u$ Zaporizkiy oblasti u 2016 rotsi [Regional report on the state of the environment in Zaporizhzhia region in 2016]. Retrieved from: https://www.zoda.gov.ua/files/WP_Article_File/original/000085/85864.pdf [in Ukrainian].

4. Hydrogeological basis for the protection of groundwater. Center for International Projects of the State Committee for Science and Technology. (1984) P. 171-177 [in Russian].

5. Shestopalov V., Lialko V., Hudzenko V. and other. (2005). Groundwater is a resource strategic.Visnyk NAN Ukrainy, Issue 5, P. $32-38$ [in Ukrainian].

6. Sanina I.V., Lyuta N.G., Lushchyk A.V. (2009). Criteria for evaluating the ecological state of geological environment at regional ecological and geological research, Kyiv, P. 28-41, 42-44 [in Ukrainian].

\section{ВПЛИВ ЛЮДСЬКОГО ФАКТОРА НА ГІДРОГЕОЛОГІЧНИЙ СТАН ТЕРИТОРІЙ НА ПРИКЛАДІ ЗАПОРІЗЬКОЇ ОБЛАСТІ}

\begin{abstract}
Анотація. Забезпечення необхідної експлуатащійної надійності будівель $i$ споруд у разі підтоплення міської території грунтовими та техногенними водами потребує подальшого розвитку методів оцінки архітектурно-будівельної системи, яка взаємодіє з екологічно шкідливим природним і техногенним навколишнім середовищем. Метою статті є аналіз міських, геотехнічних та геоекологічних особливостей інженерної інфраструктури території; класифікація негативних факторів підтоплення, що погіршують умови експлуатаиії об'єктів містобудування; класифікація та вибір заходів, спрямованих на підвищення експлуатаиійної надійності основ та фундаментів, будівель та споруд міста під впливом негативних факторів підтоплення. У результаті широкомасштабного підйому грунтових вод, переміщених до верхньої товщини лесистих суглинків, суттєво збільшилась їх мінералізаціл, через що підземні води перестали використовуватися як питні $і$ внаслідок $і x$ агресивності стосовно будівельних матеріалів почали сприяти прочесам корозії. Проблеми захисту міських будівель від негативних наслідків затоплення підземними та рукотворними водами впливають на багато аспектів інженерної діяльності, $і$ це характерно для сучасних урбанізованих територій. Для успішного здійснення повномасштабних заходів щодо захисту об'єктів інженерної інфраструктури міста від підтоплення та з метою розробки
\end{abstract}


інженерних заходів, спрямованих на забезпечення експлуатаційної надійності будівель і споруд, необхідно розробляти повнофункціональну мунічипальну міську інформаційну систему. Ключові слова: гідрогеологічні умови, підземні води, водопропускні споруди, будівля, міська інформаційна система.

\section{Бобраков А.А.}

ORCID: 0000-0002-7915-2642

к.т.н., доцент, доцент кафедри будівельного виробництва та управління проєктами, Національний університет «Запорізька політехніка», м. Запоріжжя

Щербина Л.В.

ORCID: 0000-0002-1870-5127

к.т.н., доцент, доцент кафедри будівельного виробництва та управління проєктами, Національний університет «Запорізька політехніка», м. Запоріжжя

Доненко I.B.

ORCID: 0000-0002-0017-9018

к.т.н., доцент кафедри будівельного виробництва та управління проєктами, Національний університет «Запорізька політехніка», м. Запоріжжя

Іщенко О.Л.

ORCID: 0000-0002-4152-6135

старший викладач кафедри будівельного виробництва та управління проєктами

Національний університет «Запорізька політехніка», м. Запоріжжя 